\title{
PENTA-N-SULPHOMETHYL-POLYMYXIN B (THIOSPORIN) IN THE TREATMENT OF CORNEAL INFECTION*
}

BY

\author{
D. AINSLIE \\ London
}

AN evaluation of the properties of polymyxin $E$ was made and described in this journal by Ainslie and Smith in 1952. It was found that therapeutic quantities of the antibiotic penetrated into the aqueous humour and cornea following subconjunctival injection. The injection did not appear to cause any permanent damage to the eye, but conjunctival suffusion and chemosis persisted for several days.

In 1953 a series of cases of Pseudomonas pyocyanea corneal infections in man treated satisfactorily with subconjunctival polymyxin E was reported (Ainslie, 1953). The markedly irritating properties of the preparation were, however, a great disadvantage, especially when more than a single injection was required.

Recently a new form of polymyxin, penta- $n$-sulphomethyl-polymyxin B, usually called Thiosporin, has been developed. Although it is as therapeutically active as the original preparation it is only very slightly irritating when administered by intramuscular injection. The drug has also been administered intraventricularly in the treatment of Ps. pyocyanea meningitis with relatively little toxic effect (Clifford and Stewart, 1961). It was decided to test the properties of Thiosporin in relation to the eye.

\section{Characteristics}

Thiosporin is a white crystalline powder which dissolves readily in water; $1,000,000$ units can be dissolved in $1 \mathrm{ml}$. of water to form a slightly viscous solution.

Local Toxicity and Penetration into the Aqueous.-Thiosporin, 500,000 units, dissolved in $0.5 \mathrm{ml}$. of pyrogen-free water was injected subconjunctivally into 6 anaesthetized rabbits.

Aqueous samples were taken at 45 minutes, 90 minutes, and 120 minutes by puncture of the cornea, using a fine No. 20 Record needle. About $0.2 \mathrm{ml}$. of aqueous was withdrawn in each case. An additional aqueous sample was taken from a seventh anaesthetized rabbit which had received no Thiosporin. In every case, the subconjunctival injection was given above and caused a large subconjunctival bleb. There was an almost complete absence of immediate inflammatory response. Twenty-four hours later there was slight chemosis and hyperaemia at the injection site in all cases. The conjunctiva did not appear irritable and there was no corneal oedema.

* Received for publication June 5, 1964. 
Assays of aqueous fluids were performed (Dr. Bushby, of the Wellcome Foundation) and in each sample the concentration of Thiosporin was in excess of the therapeutic level required to overcome most strains of Ps. pyocyanea. The individual results are shown in the following Table:

TABLE

RESULTS OF THIOSPORIN INJECTIONS IN SEVEN RABBITS

\begin{tabular}{c|c|c|c}
\hline Rabbit & $\begin{array}{c}\text { Thiosporin injected } \\
\text { Subconjunctivally } \\
\text { (Units) }\end{array}$ & $\begin{array}{c}\text { Aqueous } \\
\text { withdrawn } \\
\text { (min.) }\end{array}$ & $\begin{array}{c}\text { Concentration } \\
\text { of Thiosporin } \\
\text { in Aqueous } \\
\text { (Units per ml.) }\end{array}$ \\
\hline 1 & Nil & After 90 & Less than 5 \\
2 & 500,000 & After 120 & 140 \\
3 & 500,000 & After 120 & 160 \\
4 & 500,000 & After 90 & 400 \\
5 & 500,000 & After 90 & 95 \\
6 & 500,000 & After 45 & 750 \\
7 & 500,000 & After 45 & 140 \\
\hline
\end{tabular}

\section{Experimental Corneal Infections}

Infection was introduced into the cornea by intra-corneal injection of $0.02 \mathrm{ml}$. of $10^{-3}$ dilution of a 24-hour broth culture of Ps. pyocyanea. Two sets of experiments were performed as follows:

(1) The corneae of 5 rabbits were injected with Ps. pyocyanea and a few minutes later a subconjunctival injection of 500,000 units of Thiosporin was given. One rabbit received Ps. pyocyanea but no Thiosporin. Rapid infection developed in the untreated animal. Twenty-four hours later there was no sign of infection in any of the treated cases. The intra-corneal needle tracks were just visible, but even these became reduced to the faintest nebulae within a week.

(2) In the second series results were similar. Two rabbits received Ps. pyocyanea alone, and in 6 the Ps. pyocyanea was followed by a subconjunctival injection of Thiosporin $(500,000$ units). The corneae of both untreated rabbits became rapidly infected but none of the treated cases showed any sign of infection.

\section{Clinical Use}

Two patients have been treated with Thiosporin administered subconjunctivally. In both the characteristic appearance of corneal infection from a Gram-negative bacillus was present. There was a deep disc of infiltration in the cornea surrounded by a further ring of infiltrate outside the main area of infection. In both cases there was a hypopyon present. The clinical appearances, therefore, were of Gram-negative bacillary infection, but no growth was obtained on culture. However, both patients were already receiving topical antibiotic treatment. Treatment with Thiosporin applied subconjunctivally resulted in rapid improvement followed by complete resolution of the infection. 


\section{Case Reports}

Case 1, a man aged 42, had a previous history of recurrent dendritic ulcer. In June, 1963, he complained that the eye had been red and sore for three days. He was found to have a severe central corneal ulcer surrounded by a deep ring of infiltrate. A hypopyon was present. He had been treated with chloromycetin drops. Culture produced no growth.

He was admitted to hospital and chloromycetin drops were continued 4-hourly and $500 \mathrm{mg}$. of Soframycin was given subconjunctivally on admission. In addition, atropine was instilled twice daily. After forty-eight hours the condition was unchanged and two further subconjunctival injections of Soframycin were given at 2-day intervals, but there was still no improvement. Thiosporin was then given subconjunctivally and repeated twice at 2-day intervals. On each occasion the dose was 500,000 units dissolved in $1 \mathrm{ml}$. of water. There was no untoward reaction following the injections and there was slight improvement twenty-four hours after the first injection. Subsequently, improvement was rapid and the patient was discharged seven days after the final Thiosporin injection.

When last seen in February, 1964, there was a dense nebula, but the eye was quiet and well healed.

Case 2, a woman aged 73, was aphakic. Post-operative aphakic glaucoma had developed, but this had been controlled by di-isopropyl fluorophosphate 0.01 per cent. applied twice daily. The central area of the cornea was clear, but slight epithelial oedema persisted below. Otherwise the eye was quiet. In December, 1963, the patient noticed that the eye was sticky, and Sulphacetamide drops were applied; however, the eye became more inflamed and vision deteriorated.

On examination, there was a small intra-corneal abscess in the lower part of the cornea surrounded by a ring of dense infiltrate. The remainder of the cornea was oedematous. There was a small hypopyon. Culture produced no growth. On admission, a subconjunctival injection of Soframycin $(250 \mathrm{mg}$.) was given and the dose repeated the following day. The infiltrate continued to extend, however, and as the appearance was very suggestive of a Gram-negative bacillary infection, 500,000 units of Thiosporin were given and this dose was repeated forty-eight hours later. Polyfax ointment was applied 4-hourly. The hypopyon disappeared rapidly and the infiltrate started to resolve. After a week the infection appeared to have been completely overcome. Corneal oedema persisted below and Polyfax ointment was continued. Slight oedema of the lower part of the cornea was still present in March, 1964, and Polyfax ointment is being continued. The eye is entirely quiet.

\section{Discussion}

The experiments which have been described indicate that Thiosporin is at least as effective against $P$ s. pyocyanea as the earlier polymyxins, but that its local toxicity is markedly less. Only two instances of corneal infection diagnosed on clinical grounds as being due to Gram-negative bacilli have been seen, and in neither of these could bacteriological confirmation be obtained.

The much-reduced incidence of such infections appears to be largely due to the wider prophylactic use of broad-range antibiotics in the treatment of ocular injuries. The topical application of mixtures of neomycin, polymyxin, and bacitracin and the subconjunctival injection of Soframycin have been particularly valuable in this respect. Nevertheless, polymyxin has been proved highly effective in the treatment of infections due to Ps. pyocyanea and other Gram-negative bacilli, and should always be considered when such infections are suspected.

Clinical experience with Thiosporin is very limited but it does appear that this new form of polymyxin is both therapeutically active and well tolerated by the tissues. 


\section{Summary}

1. Penta- $n$-sulphomethyl-polymyxin B (Thiosporin) is described.

2. Experiments indicate that it is well tolerated when injected subconjunctivally.

3. Subconjunctival injection in rabbits leads to a high aqueous concentration.

4. Experimentally, subconjunctival injection of 500,000 units will prevent infection from developing after a massive dose of Ps. pyocyanea injected intra-corneally.

5. Two cases treated with Thiosporin are reported.

I am greatly indebted to Dr. Bushby for kindly undertaking the assays of the aqueous fluids and to the Wellcome Foundation for supplying the Thiosporin. I would also like to thank Professor Norman Ashton of the Department of Pathology at the Institute of Ophthalmology for arranging the supply of the suspensions of Ps. pyocyanea used in the experimental studies. I wish to thank Mr. Charles Cook for allowing me to observe and record Case 1. My thanks are also due to Mr. Davy of the Research Department of the Institute of Ophthalmology for his technical assistance.

\section{REFERENCES}

AinsLie, D. (1953). Brit. J. Ophthal., 37, 336.

and SмIтH, C. H. (1952). Ibid., 36, 352.

Clifford, H. E., and StewarT, G. T. (1961). Lancet, 2, 177. 